\title{
ПОРІВНЯЛЬНА ОЦІНКА ВПЛИВУ ВИРОЩУВАННЯ ТЕЛИЦЬ І ГОДІВЛІ КОРІВ НА НАДОЇ
}

\author{
Шабля Володимир Петрович \\ доктор сільськогосподарських наук, профресор \\ Луганський національний аграрний університет. \\ ORCID: 0000-0001-6510-5397 \\ Email: shabliavladimir@gmail.com \\ Задорожна Ірина Юліянівна \\ кандидат сільськогосподарських наук, ст. науковий співробітник, \\ Інститут тваринництва НААН України \\ ORCID: https://orcid.org/0000-0002-1723-0297 \\ Email: PetjaNap@yandex.ua \\ Шабля Петро Володимирович \\ магістр з економічної кібернетики \\ Інститут тваринництва НААН України \\ ORCID: https://orcid.org/0000-0003-1168-2783 \\ Email: PetjaNap@yandex.ua
}

Викладено результати досліджень щодо впливу інтенсивності вирощування телиць і рівня годівлі корів на надої у високопродуктивному стаді фермерського господарства «Альфра». З'ясовано механізми та закономірності иього впливу. Матеріалом для досліджень послужили дані про надої, витрачання кормів та вирощування телиць у різні періоди функиіінування господарства. Зокрема, контролювали вказані показники у два трирічних періоди: попередній - 2007 по 2009 рік; та наступний - з 2012 по 2014 рік. Було проаналізовано динаміку надоїв та основних показників годівлі й вирощування молодняку за попередній та наступний періоди. 3 використанням дисперсійного аналізу встановлено вірогідність відмінностей між надоями, рівнем вирощування та годівлі у різні контрольовані періоди, а також ступені та характеристики впливів періоду на вказані показники. 3 метою розробки моделі оцінки надою за показниками рівнів годівлі корів та інтенсивності вирощування телиць застосовували покроковий множинний регресійний аналіз з використанням у якості залежної змінної річних надоїв, а у якості незалежних змінних - різних показників годівлі й вирощування телиць. Виявлено, що надої на фруражну корову у ФГ «Альфра» з плином часу закономірно підвищуються. Так, при середніх надоях у попередній період (2007-2009 роки) 6062 ка, в наступному періоді (2012-2014 роки) вони збільшилися до 7838 кг, тобто на 1776 кг. Ступінь впливу періоду на надій становить $\eta^{2}=88,2 \%$ ( $\left.p=0,005\right)$. Вплив ураховуваного періоду на середньодобовий приріст телиць дорівнює $\eta^{2}=72,3 \%$. При цьому середньодобовий приріст телиць на вирощуванні збільшився з 640 г у попередній до 817 г у наступний період, або на 27,7 \% при вірогідній різниці між періодами (p =0,032). Динаміка витрат кормів на годівлю корів протягом проаналізованого відрізку часу мала позитивну тенденцію. Зокрема, у 2012-2014 роках рівень годівлі корів становив у середньому 80,4 и к.од. на корову за рік, а порівняно з попереднім періодом він збільшився на 17,2 и к.од. (27,2 \%). Однак ия різниия не вірогідна ( $p=0,083)$. Ще один важливий контрольований нами показник годівлі - кількість витрачених концентрованих кормів. Встановлено, що відсоток концентрованих кормів у структурі раціонів збільшився з 32,6 \% у попередній до 36,9 \% у наступний період, хоча ця різниця $(4,6 \%$ є) є не вірогідною ( $p=0,267)$. Розроблено досить точну $\left(R^{2}=0,979\right)$ та вірогідну $(p=0,001)$ регресійну модель прогнозування надою на фуражну корову на основі показників живої маси телиць у віці 18 місяців та частки концентрованих кормів у раціонах. Жива маса телиць у віці 18 місяиів має значно більший вплив на прогнозований надій, аніж частка концентрованих кормів, про що свідчать

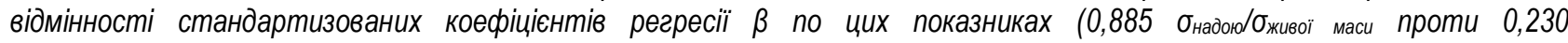

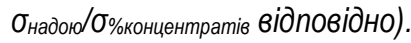

Ключові слова: худоба, , корова, телиия, надій, годівля, вирощування, маса, модель, прогнозування.

DOI: https://doi.org/10.32845/bsnau.Ivst.2019.1-2.16

Інтенсифікація вирощування телиць і гарна годівля корів - одні $з$ найважливіших зоотехнічних прийомів збільшення кількості продукції великої рогатої худоби. Від цих факторів у значній мірі залежить стан молочного скотарства як у племінних, так і в товарних господарствах, які закуповують племінних тварин для удосконалення своїх стад.

На основі поліпшення кормової бази й вирощування молодняку можливо істотно підвищити продуктивність худоби, забезпечити стійке зростання виробництва продукції тваринництва [1-3].
Реалізація програм якісного покращення великої рогатої худоби молочних і молочно-м'ясних порід шляхом використання кращого світового генофоонду, створення нових порід, типів і ліній тварин зумовлюють залучення до селекційного процесу великої кількості паратипічних, біологічних, екологічних, технологічних, статистичних та інших показників і характеристик [4-9].

Інтенсивний породоутворювальний процес одержав широке розповсюдження як у базових та племінних, так і в товарних господарствах. Тому одержано різноманітний племінний матеріал, котрий необхідно 3 належною опера- 
тивністю вивчати, узагальнювати і з урахуванням цього приймати рішення по формуванню масивів тварин бажаного типу. При цьому має місце висока варіабельність базових (племінних) господарств за якістю тварин, яка знаходиться в прямій залежності від рівня кормозабезпеченості та інтенсивності вирощування телиць [10-14].

Всі перелічені вище чинники мають місце у більшості господарств України. Однак констатація наявності їхніх впливів не дає змоги зрозуміти, який із них має вирішальне, а який додаткове значення в конкретному випадку.

Мета досліджень - порівняльна оцінка впливу годівлі та рівня вирощування телиць на позитивну динаміку молочної продуктивності корів у високопродуктивному стаді.

Матеріали та методи досліджень. Дослідження було проведено у фермерському господарстві "Альфа" Золочівського району Харківської області, де останнім часом досягнуто суттєвого прогресу за молочною продуктивністю корів. Тваринництво ФГ "Альфа" спеціалізується на розведенні великої рогатої худоби молочного напрямку продуктивності. В господарстві розводяться тварини української чорно-рябої молочної породи.

Частина худоби утримується у тваринницьких приміщеннях (ферми для корів та молодняку) на прив'язі, а частина - безприв'язно. Те ж саме можна сказати і щодо різних сезонів року. Відносно стабільним протягом тривалого часу залишалася кількість корів - 263-300 голів.

Матеріалом для досліджень послужили дані про надої, витрачання кормів та вирощування телиць у різні періоди функціонування господарства. Зокрема, контролювали вказані показники у два трирічних періоди: попередній - з 2007 по 2009 рік; та наступний - з 2012 по 2014 рік.

Було проаналізовано динаміку основних показників годівлі й вирощування молодняку за попередній період та на основі порівняння цих впливаючих чинників з надоями у різні періоди зроблено висновки щодо їхнього впливу на зростання молочної продуктивності у наступний період. Проаналізовано результативність застосованих раніше методів та прийомів поліпшення годівлі, вирощування та племінної роботи.

Крім того, такий аналіз дає змогу обґрунтувати шляхи розвитку господарства на найближчу перспективу, задля подальшого підвищення продуктивності худоби.

3 використанням дисперсійного аналізу встановлено вірогідність відмінностей між надоями, рівнем вирощування та годівлі у різні контрольовані періоди, а також ступені та характеристики впливів періоду на вказані показники.

3 метою розробки моделі оцінки надою за показниками рівнів годівлі корів та інтенсивності вирощування телиць застосовували покроковий множинний регресійний аналіз з використанням у якості залежної змінної річних надоїв, а у якості незалежних змінних - різних показників годівлі й вирощування телиць.

Регресійний і дисперсійний аналізи, а також розробку моделі здійснювали за допомогою пакету статистичного аналізу SPSS-22, процедури «Регресія - Лінійна» і «Загальна лінійна модель - Одномірна».

Результати досліджень. Нашими дослідженнями встановлено, що надої на фуражну корову у ФГ «Альфа» в попередній і наступний контрольовані періоди (табл. 1) вірогідно відрізняються ( $p=0,005)$. Так, при середніх надоях у попередній період (2007-2009 роки) 6062 кг, в наступному періоді (2012-2014 роки) вони збільшилися до 7838 кг, тобто на 1776 кг. Ступінь впливу періоду на надій становить $\eta_{\mathrm{x}}^{2}=88,2 \%$

Таблиця 1

Продуктивність великої рогатої худоби

\begin{tabular}{|c|c|c|c|c|}
\hline \multirow{3}{*}{ Показники } & \multicolumn{4}{|c|}{ Періоди } \\
\hline & \multicolumn{2}{|c|}{ Попередній } & \multicolumn{2}{|c|}{ Наступний } \\
\hline & Роки & Величина & Роки & Величина \\
\hline \multirow{3}{*}{ Надій, кг } & 2007 & 5545 & 2012 & 7503 \\
\hline & 2008 & 6497 & 2013 & 8001 \\
\hline & 2009 & 6143 & 2014 & 8010 \\
\hline \multirow{3}{*}{ Середньодобовий приріст ВРХ, г } & 2007 & 616 & 2012 & 606 \\
\hline & 2008 & 687 & 2013 & 696 \\
\hline & 2009 & 642 & 2014 & 728 \\
\hline \multirow{3}{*}{ в тому числі телиць } & 2007 & 616 & 2012 & 710 \\
\hline & 2008 & 657 & 2013 & 872 \\
\hline & 2009 & 646 & 2014 & 870 \\
\hline
\end{tabular}

Подібні тенденції мають місце й щодо середньодобових приростів телиць на вирощуванні. Зокрема, цей показник збільшився з 640 г у попередній до 817 г у наступний період, або на 27,7 \% при вірогідній різниці між періодами (р $=0,032)$. Вплив контрольованого періоду на середньодобовий приріст телиць дорівнює $\eta_{\mathrm{x}}^{2}=72,3 \%$.

Додатковими характеристиками вирощування телиць у наших дослідженнях були показники розвитку ремонтного молодняку в різному віці. Слід відмітити, що відносно стандартів за живою масою телиць і нетелей української чорнорябої молочної породи, а також порівняно з показниками господарства кінця 2000-х років (табл. 2) у наступному періоді (табл. 3) спостерігається позитивна динаміка.
Так, середня жива маса телиць усіх груп протягом трьох років наступного періоду приблизно дорівнювала або перевищувала стандарт породи.

Середньодобові прирости на вирощуванні телиць у 2014 році становили: до 6 місяців 745 г, від 6 до 12 місяців 647 г, від 12 до 18 місяців 712 г. Якщо порівняти ці показники з 2009 роком (636 г, 729 г і 597 г відповідно), то стає очевидним, що погіршилися середньодобові прирости за період від 6-ти до 12-місячного віку. А це найблагодатніший час з точки зору ефективності конверсії дешевих кормів у приріст живої маси. Крім того, це період, коли навіть деяке ожиріння незначно впливає на подальшу відтворну фуннкцію, оскільки час для осіменіння ще не настав і $€$ можливість у подальшому виправити вади вирощування. 
Таким чином, господарству доцільно в майбутньому зберігати існуючу, близьку до оптимальної, технологію вирощування телиць до 6-місячного віку і впроваджувати заходи щодо доведення середньодобових приростів до рівня 750-800 г у телиць і нетелей після 6-місячного віку.

Жива маса ремонтних телиць і корів у різному віці в попередній період

\begin{tabular}{|c|c|c|c|c|c|c|}
\hline \multirow{2}{*}{ Групи тварин } & \multicolumn{2}{|c|}{2007} & \multicolumn{2}{|c|}{2008} & \multicolumn{2}{|c|}{2009} \\
\hline & голів & жива маса, кг & голів & жива маса, кг & гол. & жива маса, кг \\
\hline телиці у 6 місяців & 122 & 158 & 110 & 148 & 139 & 156 \\
\hline телиці у 12 міс. & 110 & 276 & 131 & 272 & 130 & 289 \\
\hline телиці у 18 міс. & 54 & 377 & 113 & 398 & 108 & 398 \\
\hline Корови I отелення & 55 & 498 & 66 & 509 & 51 & 513 \\
\hline |І отелення & 69 & 567 & 57 & 565 & 78 & 554 \\
\hline III отелення & 99 & 617 & 108 & 598 & 122 & 601 \\
\hline Всього по стаду корів & 223 & 570 & 231 & 564 & 251 & 569 \\
\hline
\end{tabular}

Жива маса ремонтних телиць і корів у різному віці в наступний період

\begin{tabular}{|c|c|c|c|c|c|c|}
\hline \multirow{2}{*}{ Групи тварин } & \multicolumn{2}{|c|}{2012} & \multicolumn{2}{|c|}{2013} & \multicolumn{2}{|c|}{2014} \\
\hline & голів & жива маса, кг & голів & жива маса, кг & гол. & жива маса, кг \\
\hline телиці у 6 місяців & 147 & 169 & 173 & 173 & 157 & 176 \\
\hline телиці у 12 міс. & 124 & 293 & 164 & 299 & 142 & 294 \\
\hline телиці у 18 міс. & 116 & 422 & 146 & 438 & 137 & 424 \\
\hline Корови I отелення & 74 & 499 & 63 & 508 & 69 & 540 \\
\hline ІІ отелення & 51 & 558 & 73 & 561 & 56 & 571 \\
\hline III отелення & 115 & 597 & 112 & 593 & 121 & 595 \\
\hline Всього по стаду корів & 240 & 558 & 248 & 562 & 246 & 574 \\
\hline
\end{tabular}

При цьому візуальним оглядом поголів'я молодняку було виявлено тенденцію схильності до ожиріння деяких груп телиць старшого віку і нетелей. Це негативно впливає на ефективність їх осіменіння й отелення. Тому вважаємо за необхідне наголосити на контролі вгодованості телиць і нетелей; яка повинна бути у межах 3 - 4 балів. У випадку виявлення того факту, що значна частка приросту живої маси певних груп телиць або нетелей у певний період вирощування досягається за рахунок відкладення жиру (вгодованість вища за 4 бали), слід скоригувати раціон годівлі цих вікових груп у сторону зменшення енергії в раціоні i, можливо, збільшення кількості доступного для перетравлення протеїну.

Можливий варіант, коли жиріють лише деякі телиці (нетелі) з групи. У такому випадку бажаний індивідуальний підхід до оцінки вгодованості маток і формування окремих груп - 1) надто жирних 2) нормальної вгодованості) і 3) занадто худих - з відповідною різною годівлею.

У процесі аналізу годівлі корів установлено, що у ФГ "Альфа" досить високий рівень витрачання кормів на годівлю тварин (табл. 4, 5), який протягом останніх трьох років коливався в межах 66,2-84,0 ц к.од. на умовну голову за рік. Щодо динаміки витрат кормів на годівлю корів, то у 20122014 роках він становив у середньому 80,4 ц к.од. на корову за рік. Порівняно з попереднім періодом, середній рівень годівлі збільшився на 17,2 ц к.од. (27,2 \%), однак ця різниця не вірогідна $(p=0,083)$.

Ще один важливий контрольований нами показник годівлі - кількість витрачених концентрованих кормів, який часто використовується різними дослідниками $[1,3,12,15]$. Встановлено, що відсоток концентрованих кормів у структурі раціонів збільшився з 32,6 \% у попередній до $36,9 \%$ у наступний період, хоча ця різниця $(4,6 \%) \in$ не вірогідною ( $p$ $=0,267$ ).

Таблиця 4

Витрачання кормів у наступний період, ц к.од. за рік

\begin{tabular}{|c|c|c|c|c|c|c|}
\hline \multirow{3}{*}{ Показники } & \multicolumn{6}{|c|}{ Роки } \\
\hline & \multicolumn{2}{|c|}{2012} & \multicolumn{2}{|c|}{2013} & \multicolumn{2}{|c|}{2014} \\
\hline & всього & на 1 гол. & всього & на 1 гол. & всього & на 1 гол. \\
\hline Всього & 37274 & & 37685 & & 31670 & \\
\hline в т.ч. концентратів & 12198 & & 13472 & & 13357 & \\
\hline на 1 га с.-г. угідь & 6,03 & & 6,04 & & 4,95 & \\
\hline на 1 умовну гол. & 95,3 & 84,0 & 90,2 & 79,8 & 76,3 & 66,2 \\
\hline на корів & 25897 & 86,3 & 25687 & 85,6 & 20797 & 69,3 \\
\hline на молодняк ВРX & 9973 & 27,8 & 9875 & 22,9 & 9561 & 21,4 \\
\hline на 1 ц молока & 1,15 & & 1,07 & & 0,86 & \\
\hline на 1 ц приросту BPX & 10,56 & & 10,71 & & 10,68 & \\
\hline
\end{tabular}


Таблиця 5

Витрачання кормів у попередній (1-й) період, ц к.од за рік.

\begin{tabular}{|c|c|c|c|c|c|c|}
\hline \multirow{3}{*}{ Показники } & \multicolumn{6}{|c|}{ Роки } \\
\hline & \multicolumn{2}{|c|}{2007} & \multicolumn{2}{|c|}{2008} & \multicolumn{2}{|c|}{2009} \\
\hline & всього & на 1 гол. & всього & на 1 гол. & всього & на 1 гол. \\
\hline Всього & 28319 & & 29258 & & 34566 & \\
\hline в т.ч. концентратів & 9878 & & 9888 & & 10020 & \\
\hline на 1 га с.-г. угідь & 4,9 & & 5,1 & & 6,0 & \\
\hline на 1 умовну голову & 28319 & 51,1 & 29258 & 52,1 & 34566 & 59,3 \\
\hline на корів & 14699 & 55,9 & 16836 & 60,8 & 21839 & 72,8 \\
\hline на молодняк ВРХ & 12942 & 26,7 & 12366 & 26,0 & 12686 & 26,9 \\
\hline на 1 ц молока & 1,01 & & 0,94 & & 1,19 & \\
\hline на 1 ц приросту ВРХ & 11,87 & & 10,38 & & 11,47 & \\
\hline
\end{tabular}

Показовим можна вважати 2014 рік, в якому, наприклад, загальне витрачання кормів на корову було на $20 \%$ нижчим порівняно з двома попередніми роками. У той же час молочна продуктивність за цей же період зросла. Вважаємо, що це досягнуто за рахунок збільшення частки концентрованих кормів у раціонах великої рогатої худоби (підвищилася на 10,8 \%), а також підвищення якості кормів.

Збільшення молочної продуктивності при скороченні загальних витрат кормів свідчить про те, що орієнтація на збільшення частки концентрованих кормів та підвищення їх якості $€$ ефрективною. Зокрема, даний факт підтверджує тезу, що подальший ріст рівня годівлі (понад 60 ц к.од. на корову в рік) може призвести до росту молочної продуктивності лише за умови поліпшення якості кормів, в першу чергу збільшення концентрації енергії і протеїну в розрахунку на суху речовину корму, або на клітковину. Це узгоджується 3 дослідженнями А. Дужака [12] та Р.І. Бутило [16].

Наведені вище показники вирощування телиць і годівлі було використано для розробки моделі оцінки на їх основі надою на фуражну корову. У результаті застосовування покрокового множинного регресійного аналізу було отримано підсумкову модель, до якої (після відкидання незначущих чинників) увійшло два впливаючих фактора (табл. 6).

Ця модель досить точно $\left(R^{2}=0,979\right)$ та вірогідно $(p=$ $0,001)$ описує основні закономірності, які мають місце між характеристиками годівлі й вирощування, з одного боку, та молочною продуктивністю, з іншого. 3 її допомогою можливо досить точно оцінити й спрогнозувати, на який середній надій може розраховувати господарство при застосуванні тієї чи іншої конфігурації величин цих двох чинників.

Таблиця 6

Модель оцінки надоїв ( $y$, кг молока) у господарстві за сукупністю характеристик годівлі й вирощування телиць (x)

\begin{tabular}{|c|c|c|c|c|}
\hline \multirow{2}{*}{ Показники, що увійшли до моделі } & \multicolumn{2}{|c|}{ Нестандартизовані: } & \multirow{2}{*}{$\begin{array}{c}\text { Стандарти-зований } \\
\text { коефріцієнт регресії } \beta \text {, } \\
\sigma_{y} / \sigma_{x}\end{array}$} & \multirow{2}{*}{$\begin{array}{c}\text { Рівень } \\
\text { значущості } \\
\text { р }\end{array}$} \\
\hline & Коефріцієнт регресії В & Стандартна помилка & & \\
\hline Константа (вільний член) & $-11734,3$ кг & 1230,9 & & 0,002 \\
\hline Жива маса телиць у віці 18 місяців, кг & 40,987 кг мол./кг ж.м. & 3,2 & 0,885 & 0,001 \\
\hline Частка концентрованих кормів у раціоні, \% & 54,724 кг мол. $/ \%$ конц. & 16,6 & 0,230 & 0,046 \\
\hline
\end{tabular}

При порівнянні стандартизованих коефіцієнтів регресії $\beta$ по показниках, які увійшли до моделі, можна констатувати, що жива маса телиць у віці 18 місяців має значно більший вплив на надій, аніж частка концентрованих кормів. Про суттєво менший рівень довіри до останнього показника свідчить і набагато вища ймовірність помилковості його введення до моделі $(p=0,046)$, яка близька до граничного допустимого рівня.

\section{Висновки}

1. Надої на фуражну корову у ФГ «Альфа» з плином часу закономірно підвищуються. Так, при середніх надоях у попередній період (2007-2009 роки) 6062 кг, в наступному періоді (2012-2014 роки) вони збільшилися до 7838 кг, тобто на 1776 кг. Ступінь впливу періоду на надій становить $\eta_{\mathrm{x}}^{2}=88,2 \%(p=0,005)$.

2. Вплив ураховуваного періоду на середньодобовий приріст телиць дорівнює $\eta_{\mathrm{x}}^{2}=72,3 \%$. При цьому середньодобовий приріст телиць на вирощуванні збільшився 3
640 г у попередній до 817 г у наступний період, або на 27,7 \% при вірогідній різниці між періодами ( $p=0,032)$.

3. Динаміка витрат кормів на годівлю корів протягом проаналізованого відрізку часу мала позитивну тенденцію. Зокрема, у 2012-2014 роках рівень годівлі корів становив у середньому 80,4 ц к.од. на корову за рік, а порівняно 3 попереднім періодом він збільшився на 17,2 ц к.од. (27,2 \%). Однак ця різниця не вірогідна ( $p=0,083)$.

4. Розроблено досить точну $\left(R^{2}=0,979\right)$ та вірогідну ( $p=0,001)$ регресійну модель прогнозування надою на фуражну корову на основі показників живої маси телиць у віці 18 місяців та частки концентрованих кормів у раціонах.

5. Жива маса телиць у віці 18 місяців має значно більший вплив на прогнозований надій, аніж частка концентрованих кормів, про що свідчать відмінності стандартизованих коефіцієнтів регресії $\beta$ по цих показниках $(0,885$

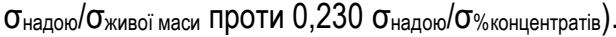

Список використаної літератури:

1.Lukuyu B., Gachuiri C.K., Lukuyu M.N., Lusweti C. and Mwendia S. (eds). 2012. Feeding dairy cattle in East Africa. East 
africa Dairy Development project, Nairobi, Kenya. ISBN: 92-9146-272-1

2.Стадницька О. І. Вплив росту і розвитку корів у період вирощування на їх молочну продуктивність // Розведення і генетика тварин. К.: Аграрна наука. 2011. Вип. 45. С. 264-270.

3.Висока продуктивність потребує додаткової енергї // Agroexpert. 2013. № 5 (58). С. 84-85.

4.Pezzuolo, A.; Chiumenti, A.; Sartori, L; Borso, F. Automatic feeding system: evaluation of energy consumption and labour requirement in north-east italy dairy farm. Engineering for rural development, v.25, p. 882-887, 2016.

5.Shablia, V.P. Comparative assessment of feed preparation technologies for Ukrainian breeds of dairy cows // Boletim de Indústria Animal I Instituto de Zootecnia. Nova Odessa. Brasil. 2018. V. 75, p.1-10. DOI: https://doi.org/10.17523/bia.2018.v75.e1424.

6.Рубан С.Ю., Перекрестова А.В., Шабля В.П. Методи оцінки ефеккивності виробництва молока коровами різних генетичних груп в умовах високотехнологічної ферми (частина перша). Науковий вісник Національного університету біоресурсів і природокористування України. Серія «Технологія виробництва і переробки продукції тваринництва». Вип. 271. Київ, 2017. C. $158-176$.

7.Шабля В.П., Шабля П.В. Комп'ютерна економетрична модель технології скотарства // Науково-технічний бюлетень IT НААН України. 2016. №115. С. 242-252.

8.Arndt, C., Powell, J.M., Aguerre, M.J., Crump, P.M., Wattiaux, M.A. (2015). Feed conversion efficiency in dairy cows: Repeatability, variation in digestion and metabolism of energy and nitrogen, and ruminal methanogens. J. Dairy Sci., 98(6), 3938-3950.

9.Ruban, S.Y.; Perekrestova, A.V.; Shablia, V.P.; Bochkov, V.M. Feed conversion efficiency in different groups of dairy cows. Ukrainian Journal of Ecology, v.8, p.124-129, 2018. doi: 10.15421/2018_196

10. Першута В. В. Взаємозв'язок рівня вирощування та молочної продуктивності корів-первісток // Розведення і генетика тварин. 2011. № 45. С. 192-199.

11. Кузів М., Кузів Н, Федорович $Є$. Вплив живої маси телиць на молокопродуктивність первісток у період вирощування // Твариннцтво України. 2015 № 9. С. 16-20.

12. Бутило Р.І. Годівля як ключовий організаційно-економічний елемент в технології виробництва молока // Інноваційна економіка. № 6 (55). 2014. С. 141-145.

13. Хмельничий Л. М., Лобода В.П. Характеристика ремонтних телиць української червоно-рябої молочної породи за розвитком живої маси // Вісник Сумського нац. агр. ун-ту, Вип. 2/2 (25). Суми, 2014. С. 10-13.

14. Литвиненко Т. В. Вікові зміни інтенсивності росту ремонтних телиць голштинської породи // Вісник СНАУ. Серія Тваринництво. 2010. № 12. С. 73-75.

15. Maekawa, M, Beauchemin, K.A., Christensen, D.A. Effect of concentrate level and feeding management on chewing activities, saliva production, and ruminal pH of lactating dairy cows. J Dairy Sci. 2002 May; 85(5):1165-75. DOI: 10.3168/jds.S00220302(02)74179-9

16. Дужак А. Якість кормів задає тон ефективній годівлі // Пропозиція. 2012. № 1. С. 117-118.

\section{References:}

1.Lukuyu B.; Gachuiri C.K.; Lukuyu M.N.; Lusweti C. and Mwendia S. (eds). 2012. Feeding dairy cattle in East Africa. East africa Dairy Development project, Nairobi, Kenya. ISBN: 92-9146-272-1

2.Stadnytska O. I. 2011. Vplyv rostu i rozvytku koriv u period vyroshchuvannia na yikh molochnu produktyvnist [Influence of growth and development of cows during the growing period on their milk productivity] // Rozvedennia i henetyka tvaryn. K.: Ahrarna nauka. issue 45. pp. 264-270.

3.Vysoka produktyvnist potrebuie dodatkovoi enerhii [High performance requires extra energy] // Agroexpert. 2013. no. 5 (58). pp. 84-85.

4.Pezzuolo, A.; Chiumenti, A.; Sartori, L. and Borso, F. 2016. Automatic feeding system: evaluation of energy consumption and labour requirement in north-east italy dairy farm. Engineering for rural development, v.25, pp. 882-887.

5.Shablia, V.P. 2018. Comparative assessment of feed preparation technologies for Ukrainian breeds of dairy cows // Boletim de Indústria Animal / Instituto de Zootecnia. Nova Odessa. Brasil. V. 75, pp.1-10. DOI: https://doi.org/10.17523/bia.2018.v75.e1424.

6.Ruban, S.Yu., Perekrestova, A.V. and Shablia, V.P. Metody otsinky efektyvnosti vyrobnytstva moloka korovamy riznykh henetychnykh hrup v umovakh vysokotekhnolohichnoi fermy (chastyna persha) [Methods for evaluating milk production efficiency by cows of different genetic groups in a high-tech farm (Part One)]. Naukovyi visnyk Natsionalnoho universytetu bioresursiv $i$ pryrodokorystuvannia Ukrainy. Seriia «Tekhnolohiia vyrobnytstva i pererobky produktsii tvarynnytstva». issue 271. Kyiv, 2017. pp. 158-176.

7.Shablia, V.P., Shablia, P.V. 2016. Kompiuterna ekonometrychna model tekhnolohii skotarstva [Computer econometric model of livestock technology] // Naukovo-tekhnichnyi biuleten IT NAAN Ukrainy. no. 115. pp. 242-252.

8.Arndt, C.; Powell, J.M.; Aguerre, M.J.; Crump, P.M. and Wattiaux, M.A. 2015. Feed conversion efficiency in dairy cows: Repeatability, variation in digestion and metabolism of energy and nitrogen, and ruminal methanogens. J. Dairy Sci., 98(6), 39383950.

9.Ruban, S.Y.; Perekrestova, A.V.; Shablia, V.P.; Bochkov, V.M. 2018. Feed conversion efficiency in different groups of dairy cows. Ukrainian Journal of Ecology, v.8, pp.124-129. doi: 10.15421/2018_196

10. Pershuta, V. V. 2011. Vzaiemozviazok rivnia vyroshchuvannia ta molochnoi produktyvnosti koriv-pervistok [The relationship between the level of production and milk production of first-born cows] // Rozvedennia i henetyka tvaryn. № 45. pp. 192-199.

11. Kuziv, M., Kuziv, N and Fedorovych Ye. 2015. Vplyv zhyvoi masy telyts na molokoproduktyvnist pervistok u period vy- 
roshchuvannia [Influence of live weight of heifers on milk production of firstborn cows during the growing period] // Tvarynntstvo Ukrainy. no. 9. pp. 16-20.

12. Butylo R.I. 2014. Hodivlia yak kliuchovyi orhanizatsiino-ekonomichnyi element v tekhnolohii vyrobnytstva moloka [Feeding as a key organizational and economic element in milk production technology] // Innovatsiina ekonomika. no. 6 (55). pp. 141-145.

13. Khmelnychyi, L. M. and Loboda V.P. 2014. Kharakterystyka remontnykh telyts ukrainskoi chervono-riaboi molochnoi porody za rozvytkom zhyvoi masy [Characteristics of repair heifers of Ukrainian Red-and-White dairy breed by development of live weight] // Visnyk Sumskoho nats. ahr. un-tu, issue 2/2 (25). Sumy, pp. 10-13.

14. Lytvynenko, T. V. 2010.Vikovi zminy intensyvnosti rostu remontnykh telyts holshtynskoi porody [Age-related changes in the growth rate of Holstein breeding heifers] // Visnyk SNAU. Seriia Tvarynnytstvo. no. 12. pp. 73-75.

15. Maekawa, M; Beauchemin; K.A. and Christensen, D.A. Effect of concentrate level and feeding management on chewing activities, saliva production, and ruminal pH of lactating dairy cows. J Dairy Sci. 2002 May; 85(5):1165-75. DOI: 10.3168/jds.S00220302(02)74179-9

16. Duzhak, A. 2012. Yakist kormiv zadaie ton efektyvnii hodivli [Feed quality sets the tone for effective feeding] // Propozytsiia. no. 1. pp. 117-118.

\section{Shablia, V.P., \\ Zadorogna, I.Yu., \\ Shablia, P.V.}

\section{Comparative evaluation of the impact growing heifers and feeding cows on milk yields}

The results of studies on the influences of heifers growing intensity and the level of feeding cows on milk yields in the highly productive herd of Alfa farm are presented. The mechanisms and patterns of this influence have been clarified. The data for the research were given on milk yields, feed consumption and heifers growing during different periods of farm functioning. In particular, these indicators were monitored in two three-year periods: the previous one - from 2007 to 2009; and the next one - from 2012 to 2014. The dynamics of milking and the main indicators of feeding and growing of young animals for the previous and next periods were analyzed. Using the analysis of variance, the significance of differences between milk yields, the level of growing and feeding in different controlled periods was established, as well as the degree and characteristics of the effects of the period on these indicators. A stepwise multiple regression analysis was used to develop a model for estimating milk yield on cows' feeding rates and heifers' growing intensities, using as a dependent variable annual milk yields, and as independent variables, different feeding and growing indices. It has been found that milk yields for feed cows in Alfa increase over time. Thus, with average milk yields in the previous period (2007-2009) $6062 \mathrm{~kg}$, in the next period (2012-2014 years) they increased to $7838 \mathrm{~kg}$, ie by $1776 \mathrm{~kg}$. The degree of influence of the period on milk yields is $\eta^{2}=88.2 \%(p=0.005)$. The impact of the considered periods on the average daily increase in heifers is $\eta^{2}=72.3 \%$. At the same time, the average daily increase of heifers' live weight changes from $640 \mathrm{~g}$ in the previous to $817 \mathrm{~g}$ in the next period, or by $27.7 \%$ at the significance of difference between the periods $(p=0.032)$. The dynamics of feed consumption for feeding cows during the analyzed period had a positive trend. In particular, at 2012-2014, the level of cows' feeding averaged 80.4 centner feed unit per cow per year, and compared to the previous period it increased by 17.2 centner feed unit (27.2\%). However, this difference is not significant $(p=0.083)$. Another important controlled indicator of feeding is the amount of concentrated feed consumed. It was found that the percentage of concentrated feed in the structure of ration increased from $32.6 \%$ in the previous to $36.9 \%$ in the next period, although this difference (4.6\%) is not significant $(p=0.267)$. An accurate $\left(R^{2}=0.999\right)$ and significant $(p=$ $0.001)$ regression model for predicting milk yields has been developed based on live weight of heifers at the age of 18-month and proportion of concentrated feeds in rations. The live weight of heifers at age of 18 months has a much greater impact on predicted milk yields than the proportion of concentrated feeds, as recorded by differences in the standardized regression coefficients $\beta$ for

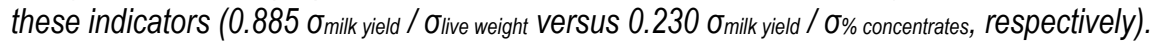

Key words: cattle, cow, heifer, milk yield, feeding, growing, mass, model, prediction

Дата надходження до редакції: 17.02.2019 p. 